\title{
The Introduction of the Philosophy of Sufficiency Economy and Its Application to Consumer Context
}

\author{
Sasawan Heingraj \\ University of Texas Rio Grande Valley \\ Suwakitti Amornpan \\ University of Texas Rio Grande Valley
}

Follow this and additional works at: https://digitalcommons.uri.edu/mgdr

Part of the Business Law, Public Responsibility, and Ethics Commons, and the Marketing Commons

\section{Recommended Citation}

Heingraj, Sasawan and Amornpan, Suwakitti (2019) "The Introduction of the Philosophy of Sufficiency Economy and Its Application to Consumer Context," Markets, Globalization \& Development Review. Vol. 4: No. 1, Article 4.

DOI: 10.23860/MGDR-2019-04-01-04

Available at: https://digitalcommons.uri.edu/mgdr/vol4/iss1/4

This Article is brought to you for free and open access by DigitalCommons@URI. It has been accepted for inclusion in Markets, Globalization \& Development Review by an authorized editor of DigitalCommons@URI. For more information, please contact digitalcommons-group@uri.edu. 
The Introduction of the Philosophy of Sufficiency Economy and Its Application to Consumer Context

\section{Cover Page Footnote}

We would like to thank the Editors and the two anonymous reviewers for helping us to improve the manuscript. We also would like to thank Fuat A. Firat and Deniz Atik for their invaluable comments. 


\section{Markets, Globalization \& Development Review}
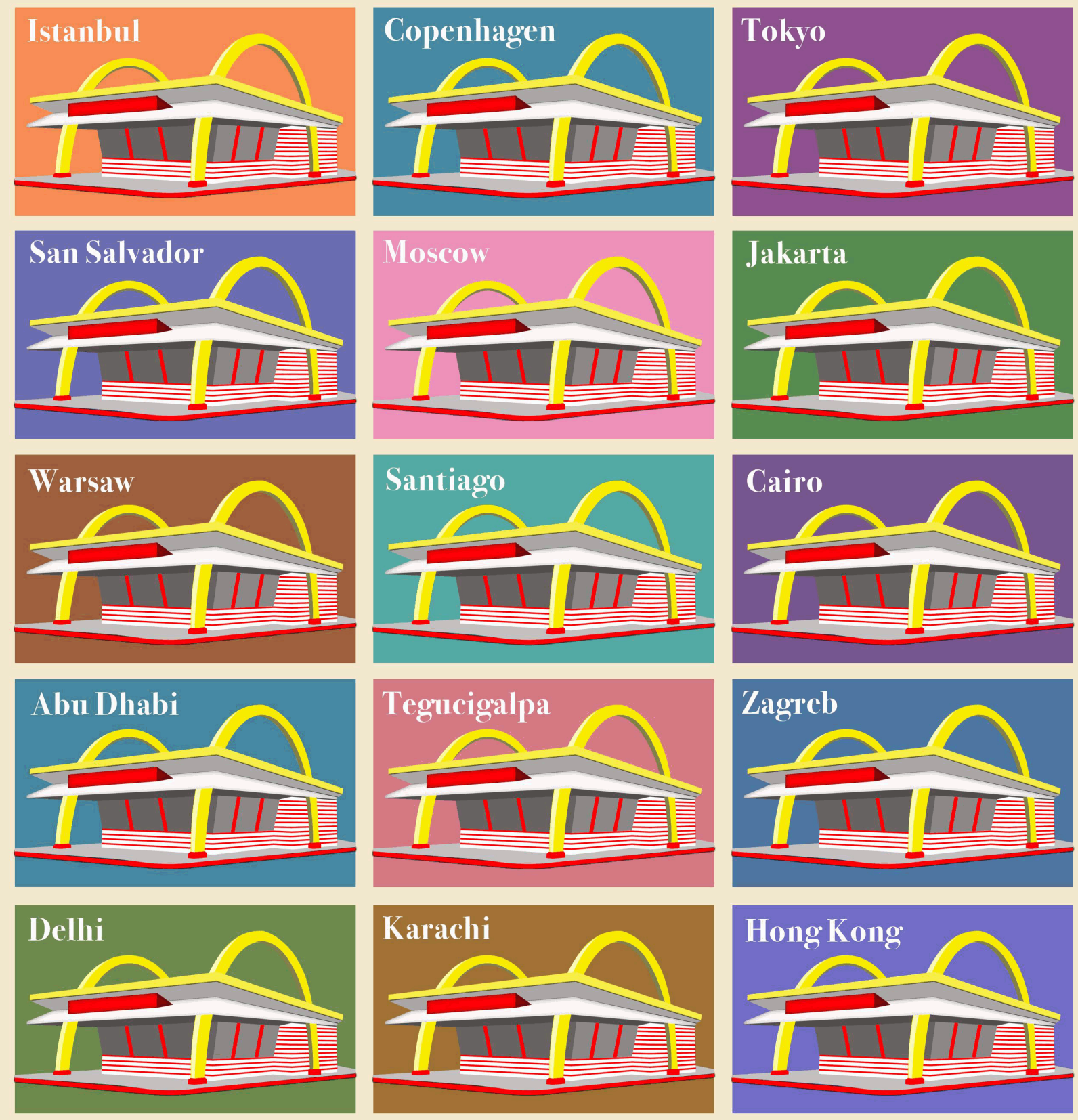

This article is available in Markets, Globalization \& Development Review: https://digitalcommons.uri.edu/mgdr/vol4/ 


\section{The Introduction of Philosophy of Sufficiency Economy and Its Application to Consumer Context}

\section{Introduction}

The concept and the effects of globalization in today's economic conditions have been widely examined for over a decade. Prior studies on globalization have defined the concept of globalization as the increment of economic interconnectedness, reduction of trade restrictions, and intensification of social relations between countries (Archibugi and lammarino 2002; Giddens 2007; Reese, Rosenmann and McGarty 2015; Scholte 2008). Individuals, therefore, can physically, legally, culturally, and psychologically engage with each other without concerning the nature of social and geographical spaces.

Globalization also generates double-edged effects on a country's economic condition. On the one hand, it can help alleviate global inequality, as well as poverty among countries (Bergh and Nilsson 2014; Bourguignon 2016). This is because globalization impels the global economy to increase international trade and diminish trade restriction. On the other hand, globalization can expand inequality within each individual country (Antràs, de Gortari and Itskhoki 2017; Bourguignon 2016). As supported by the study of Bourguignon (2016), the Gini coefficient of an individual country -the measurement of income inequality used to quantify the individual country's level of inequality ranging from 1 , i.e., referring to a perfect equality, to 0 , i.e., referring to a perfect inequality, has increased more than two percent on average from 1990 to 2010.

Furthermore, we believe that globalization has effects not only at the country level but also at the individual level, particularly by enhancing individuals' vulnerability. This paper, therefore, does not attempt to pursue any arguments relating to the nature and meaning of globalization. It, indeed, welcomes the fact that globalization can generate both positive and negative effects. Instead, the paper examines a specific case of how a country -Thailand in this case, attempts to prepare itself and its people for the effects of globalization, as well as the related inevitable changes. We also argue that the individual level dynamics play a crucial role in any society's and country's development. Thus, the well-being of each individual should be taken into consideration in order to lessen the negative effects of globalization to generate a balanced and sustainable development at the country level. 
One of the concepts that has been widely recognized, both nationally and internationally, regarding an alternative way of enhancing a more balanced way of living is the Philosophy of Sufficiency Economy (PSE). The concept of PSE was initiated by His Majesty the King Bhumibol Adulyadej of Thailand (Rama IX: 1927-2016), since 1974, to promote an awareness of the detrimental effect of the rapid economic growth and modernization. The objective of PSE is to develop the foundation of self-realization in order to establish a sustainable living and economic development in Thai society. The philosophy consists of three interconnected principles, which are moderation, reasonableness, and self-immunity, together with two basic conditions-knowledge and morality (Chaipattana 2017; Mongsawad 2010; Sornsri 2016; Tangvitoontham, Hengpatana and Kotrajaras 2015). Therefore, individuals can adapt PSE as a guideline for their daily activities in order to enhance their quality of life, as well as their well-being.

The purpose of implementing PSE is also to mitigate the overexploitation of communities and natural resources, as well as to protect individuals, local communities, and nations from the effects of excessive commercialization and globalization. Accordingly, this paper first examines how the Philosophy of Sufficiency Economy was initially developed, and then analyses the influences of this philosophy on individuals' way of life, as well as the challenges associated with it. Therefore, the following sections illustrate the concept and development of PSE, and how PSE had been implemented to alleviate the effects of globalization on Thai economy, particularly during the 1997 East Asian economic recession. Furthermore, PSE's challenges and implications in terms of an individual's daily activities are examined.

\section{The Concept of Philosophy of Sufficiency Economy}

The Philosophy of Sufficiency Economy was firstly introduced by His Majesty the King Bhumibol Adulyadej of Thailand in 1974 based on his extensive and accumulated experiences in Thailand's rural development (Chaipattana 2017; Poungsuk, Pourpan and Thongsuk 2016). This philosophy was conceptualized to reinforce a balanced way of living, as well as to hinder overconsumption which extensively occurs in today's modern society (Dayley 2011; Jairak, Praneetpolgrang and Subsermsri 2015; Mongsawad 2010; Poungsuk, Pourpan and Thongsuk 2016).

The philosophy was developed based on the Buddhist philosophical and moral principles, the agricultural characteristics of Thailand, and the fundamental principle of Thai culture (Chaipattana 2017; Jairak, Praneetpolgrang and Subsermsri 2015; Sornsri 2016). It is a method for achieving a balanced way of life based on moderation, prudence, frugality, 
and social immunity in order to better prepare individuals to be more efficient when encountering any challenges arising from modernization, globalization, and other inevitable changes (Mongsawad 2010; Piboolsravut 2004). Therefore, the goals of PSE are to generate self-realization, resilient, and sustainable development from the level of individuals, families, communities to the society at large through the emphasis on foundation building, immunities enhancement, and resilience in modernized economic condition (Chalapati 2008; Piboolsravut 2004; Wibulswasdi, Piboolsravut and Pootrakool 2011). Not only does PSE offer people with foundation leading to a balanced way of life, but it also provides people with an opportunity to shape their lives based on their own capability (Mongsawad 2010). As supported by His Majesty's definition of PSE:

Philosophy of Sufficiency Economy is to create balance and the ability to cope appropriately with critical challenges arising from extensive and rapid changes in material, social, environmental, and cultural condition in the world.

In a nutshell, PSE underlines a comprehensive concept of balanced consumption and production, while acknowledging an interconnectedness among people, society, and environment.

Since the concept of PSE provides an alternative approach to mitigate individual's vulnerability based on the emphasis of honesty, diligence, sharing, and altruism, which is the foundation of every society, it has been widely recognized at the international level. The philosophy was acclaimed and His Majesty the King Bhumibol Adulyadej was recognized as the "Developer King" during the $10^{\text {th }}$ UN Conference on Trade \& Development (UNCTAD) in February 2000.

Therefore, to equilibrate the balanced way of living and hinder overconsumption, three intertwining principles of PSE, which are moderation, reasonableness, and self-immunity, together with two basic conditions-knowledge and morality-should be taken into consideration. Figure 1 exhibits the framework of the Philosophy of Sufficiency Economy. 
Figure 1: The Framework of Philosophy of Sufficiency Economy

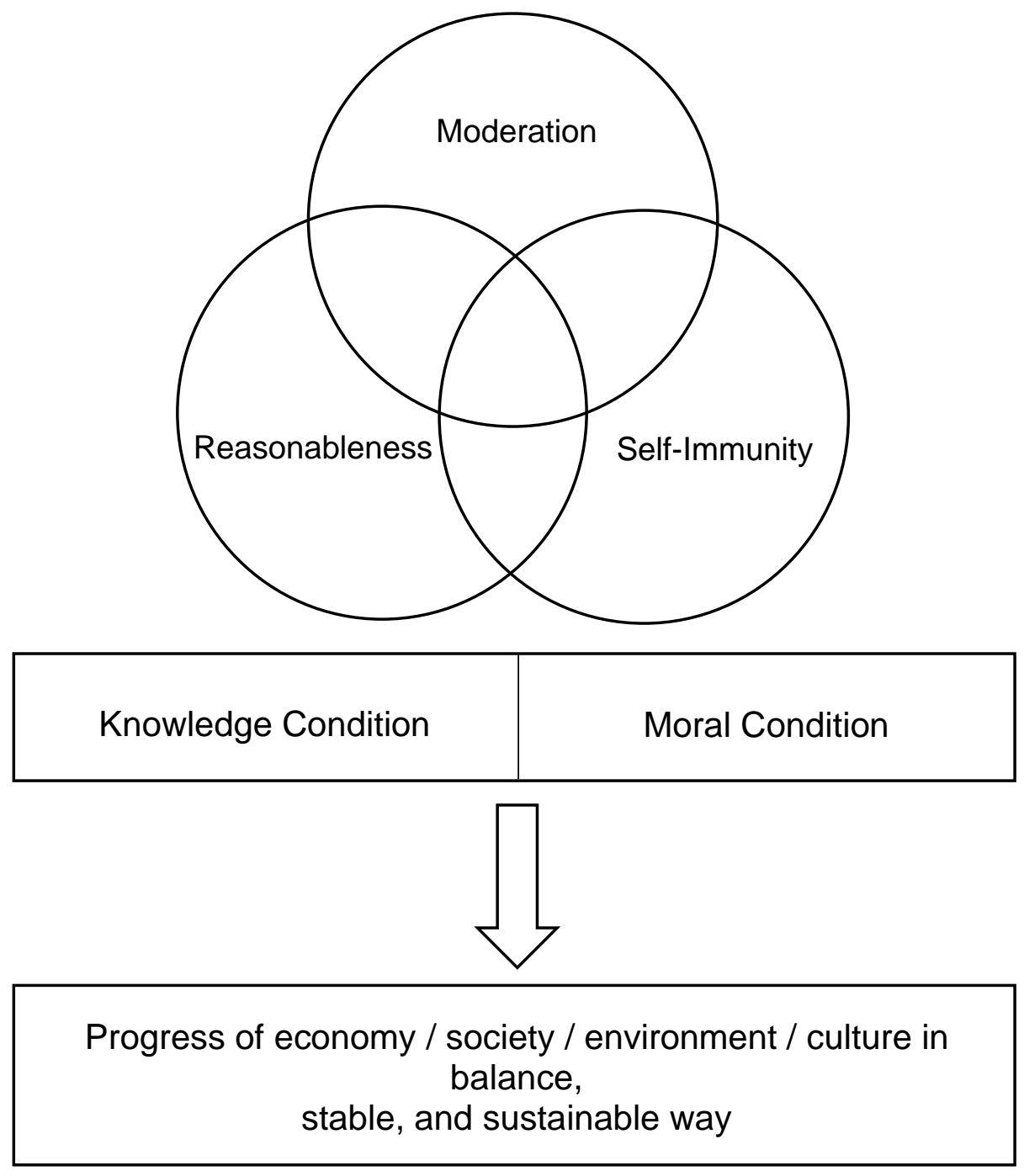

Source: Chaipattana (2017) 
Moderation exhibits a sufficient way of living through simplicity while acknowledging one's capabilities, as well as being socially and environmentally responsible (Buranapin and Ratthawatankul 2015; Chaipattana 2017; Mongsawad 2010). The practice of moderation can provide individuals with sustainable development through the fact that any decision-making will be built upon ones' accumulated knowledge, resources, and experiences. As a result, individuals are likely to base their decisions on their self-reliance by, firstly, aiming for modest goals.

Reasonableness indicates the rational decision-making that reflects the consideration of all possible outcomes and other related factors through the utilization of analytical ability, self-awareness, foresight, and empathy (Chaipattana 2017; Jairak, Praneetpolgrang and Subsermsri 2015; Pruetipibultham 2010). Therefore, individuals can apply the principle of reasonableness via an evaluation of accumulated knowledge and previous experience to better understand the consequences of each decision holistically.

Self-immunity refers to the ability of the individuals to protect themselves against any risks or unexpected circumstances resulting from uncontrollable or unpredictable factors that associate with both internal and external environment (Chaipattana 2017; Mongsawad 2010). This principle also acknowledges the importance of environmental sustainability and the conservation of local culture and wisdom that may affect individual wellbeing. Therefore, the implementation of this principle will enhance ones' ability to defend themselves from any effects of globalization, modernization, and market turbulence.

To effectively implement the aforementioned principles, two basic conditions -knowledge and morality, should be taken into consideration. Knowledge encompasses both tacit and explicit knowledge, including accumulated insights, information, experiences, and analytical ability (Chaipattana 2017; Wanasilp and Tangvitoontham 2015; Wibulswasdi, Piboolsravut and Pootrakool 2011). This knowledge is required for accurate and thorough planning in order to achieve expected results and sustainable outcomes.

Morality reflects integrity, trustworthiness, ethical behavior, honesty, perseverance, and generosity of an individual's way of life (Chaipattana 2017; Mongsawad 2010; Wibulswasdi, Piboolsravut and Pootrakool 2011). PSE perceives morality as one of the essential foundations of the economic system, and this condition also plays a vital role in generating sustainable development. Therefore, individuals with morality will be good citizens of their community and will be likely to offer help to those who are in need. 
According to the three interconnected principles of PSE, together with its two basic conditions, the PSE can be applied at both micro and macro levels, i.e., from individuals to the society at large. However, we believe that in order to bolster a balanced and sustainable development at the society level, each individual needs initially to understand the concept of PSE in order to sufficiently implement this concept to his/her daily activities.

In the present market condition, an individual can hardly refrain himself/herself from any forms of consumption such as, from satisfying his/her desire, reputation, aspired social status, to the impellent force of other external factors such as marketing and sales promotion. Therefore, PSE proposes that for an individual to obtain a balanced way of living, s/he needs to evaluate all possible options holistically through the recognition of self-reliance-the ability to tolerate and cope with any inevitable changes, as well as any possible outcomes. As an illustration, when purchasing a house, an individual who applies the concept of PSE to his/her decisionmaking process will scrutinize all available options based on his/her knowledge, experiences, and resources such as budget, house's usage space that is suitable for the size of the household, location, and price. The evaluation of all possible options through one's own knowledge, resources, and experience can be referred to the principle of moderation. At the same time, s/he needs to evaluate each option thoroughly by finding other related information or detail about each house, in terms of the neighborhood, school zone, and other criteria that need to be considered, etc. This process of meticulous evaluation regarding each option with the related information can be referred to the principle of reasonableness. Apart from the aforementioned evaluations, s/he needs to ensure that there is a backup plan in terms of any budget dedicated to resolving any problems that derived from unexpected or uncontrollable events, such as natural disasters or any effects from market turbulence or economic recession. The demonstration of this backup plan can be exemplified as the implementation of self-immunity.

Additionally, there are two conditions -knowledge and morality that need to be considered when performing the decision-making process. According to the above example, each individual who wants to purchase a house must have sufficient knowledge regarding the present market price, any related laws and regulations, present and future economic condition, and any related information regarding the sale contract and such in order to perform an adequate decision. Lastly, s/he must be aware that all decisions made, throughout the process, should be based on morality in terms of transparency and being good citizenship of a community. Therefore, the 
implementation of PSE as exemplified by the decision-making process of purchasing the house can offer individual an ability to evaluate his/her decision more sufficiently, effectively, and holistically. In other words, the implementation of PSE can enhance individual's ability to consume wisely.

Based on the concept of PSE, this philosophy can generate a balanced and sustainable development through the foundation building, enhancement of self-immunity, and resilient planning in order to provide individuals with an ability to defend themselves from any negative effects of globalization and any inevitable changes. One of the well-known examples of the unfavorable effect of globalization is the 1997 East Asian economic recession. Previous research on globalization has proposed that one of the potential causes of this economic crisis was the condemnation of the economic development plan which was launched in Thailand during 1961 (Erturk 2001; Smith 2005). This development plan emphasized the economic growth especially in the private sector through first, the exploitation of Thailand's natural resources; second, the emphasis of urban economic development through private enterprise; and third, the acquisition of technology via foreign investment (Baker and Phongpaichit 2014). The consequences of the aforementioned plan not only increased the Thai gross domestic product (GDP) particularly through the private industrial sector, but also exposed Thai people to market globalization in terms of a reduction in government intervention, privatization efforts, global market forces, an emphasis on capitalism, and liberalization of foreign investment regimes.

\section{The Implementation of Philosophy of Sufficiency Economy on Thailand's Economic Recession: The Case of 1997 East Asian Crisis}

Globalization and trade liberalization had been initially introduced to the Thai economy since 1961. Field Marshal Sarit Thanarat, who was Thailand's prime minister at that time, had established Thailand's first fiveyear economic development plan based on the consolidation between the World Bank mission and his state-led development policies (Baker and Phongpaichit 2014). As a result, starting from the mid-1990s, the Thai economy had been shifted to the more liberalized international capital market (Erturk 2001; Ghosh 2013; Smith 2005; Warr 2002).

The transformation of Thailand's economy to a liberalized economy exposed Thai people to market globalization resulting in increased economic vulnerability. Since the 1961 economic development plan was mainly focused on the privatization and liberalization of foreign investment, it enhanced Thailand's economic dependency on global market mechanisms. Prior research on globalization also proposes this economic 
transformation as one of the potential causes of the 1997 East Asian crisis (Erturk 2001; Smith 2005).

The 1997 East Asian crisis was initiated by: first, an aggravation of productivity and import-export growth, as well as an inefficiency of the exchange rate system monitored by the Bank of Thailand (BOT) (Ghosh 2013; Régnier 2017). In terms of the reduction in productivity and importexport growth, as illustrated by Cook and Devereux (2006), the import volume had declined by $20 \%$ to $40 \%$, and the export volume had declined by approximately $8 \%$ since the second quarter of 1997 . Furthermore, the BOT, that previously intervened the exchange rate system through pegging to the US dollar, announced the floating of the Thai Baht currency on July 2 , 1997, therefore, generating an immediate and significant currency depreciation of $48.7 \%$ of its value against the US dollar, i.e., from 25 Baht per US dollar to 55 Baht per US dollar, by the end of 1997 (Durham 2007; Ghosh 2013; Warr 2002).

Another manifestation of Thailand's economic vulnerability was excessive international loan and foreign direct investment, particularly in the real-estate sector. As illustrated by Durham (2007) and Warr (2002), the balance of the outstanding international loan dramatically increased from \$US 110 billion in 1990 to $\$$ US 390 billion in mid-1997. The annual foreign direct investment also significantly increased from \$US 400 million in 1987 to over $\$$ US 2 billion in 1997. This tremendous increase in international loan and foreign direct investment was associated with the depreciation of the Thai Baht currency.

To ameliorate the effect of the 1997 East Asian crisis on Thailand's economy, the Thai government espoused the financial support of \$US 20.3 billion from the International Monetary Fund (IMF). The purpose of the mentioned support from the IMF was to restructure the financial sector via the recapitalization of the Thai banking system (Durham 2007; Mahathanaseth and Tauer 2014). The application of such IMF policies, however, did not rectify the economic recession. Instead, the Thai GDP decreased, and the unemployment rate increased in comparison to the period prior to the recession (Durham 2007). Contrarily, Korea, whose economy was also impaired by this economic recession, managed its economy through the implementation of sovereignty using the segregated currency speculation (Durham 2007). As a result, its economic condition was consecutively ameliorated compared to those that implemented the IMF policies.

One of the reasons that Thailand's economy was still in disrepair after implementing the IMF's policies might be the fact that these policies were the duplication of the policies devised for rectifying the 1970s and 
1980s Latin American economic recession (Warr 2002). The IMF failed to acknowledge the sophistication and distinct characteristics regarding the nature of each economic condition. Figure 2 exhibits the increment of Thailand's household debt to GDP from 1996 -before the economic recession to $2007-10$ years after implementing the IMF's policies. Therefore, the strategies that should be implemented to mitigate the effect of the economic recession on Thailand's economy should align with its unique economic characteristics.

Since Buddhism, the national religion of Thailand, and agriculture are the dominant characteristics that shape the Thai economy (Noy 2011), the Thai government later incorporated PSE in Thailand's $10^{\text {th }}$ National Economic and Social Development Plan for the years 2007-2011. This development plan emphasized people-centered development through three capitals, including economic, social, and natural resources and environment in order to attain a green and happy society (Sachayansrisakul 2012). 
Figure 2. Thailand's Household Debt to GDP from 1996 to 2007

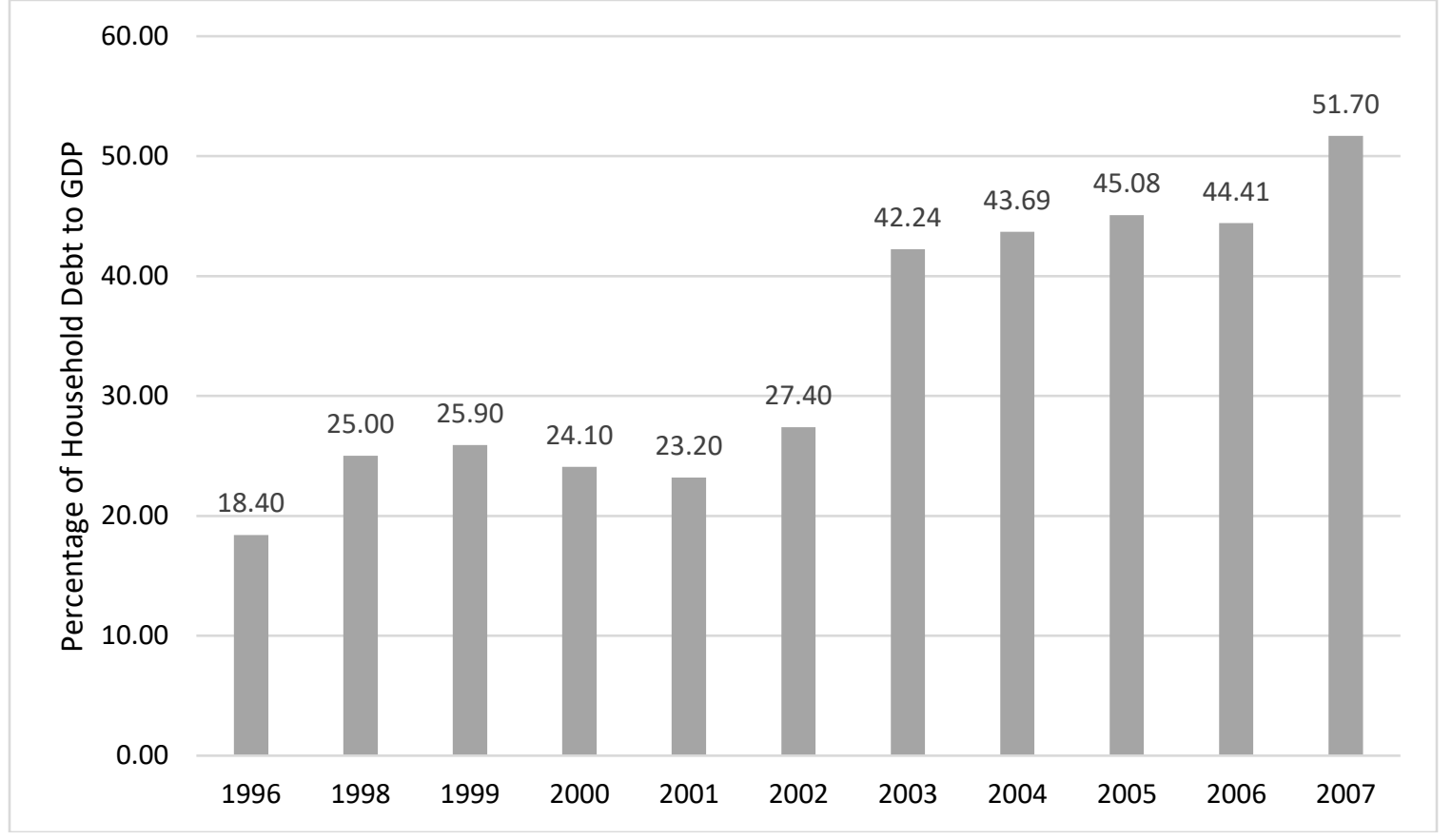

Source: International Monetary Fund (2017) 


\section{Challenges of Philosophy of Sufficiency Economy}

Although the purpose of PSE is to develop the foundation of self-reliance to establish a sustainable living and economic development in Thai society, several challenges also have arisen from the implementation of this philosophy. The first challenge falls within the misconceptions regarding the concept of PSE, which were adapted from Wibulswasdi, Piboolsravut and Pootrakool (2011). These misconceptions are; (a) the confusion regarding the concept of PSE and self-sufficiency: PSE refers to the two-stage process, which includes the basic sufficiency or relative selfsufficiency, and advanced sufficiency, respectively. The basic sufficiency indicates individual's ability to decide based on his/her self-reliance in terms of basic and individual necessities through the use of accumulated knowledge, experiences, and resources. Once these foundations are created, individuals can progress to the stage of advanced sufficiency. This stage refers to the extension regarding the utilization of one's knowledge, experiences, resources, and analytical ability in order to enhance the quality of life. Self-sufficiency, however, indicates individual's ability to maintain his/her fulfillment regarding the basic needs with no or minimal assistance from outside. In brief, the difference between PSE and self-sufficiency is that PSE, on the one hand, recognizes the importance of exchange and cooperation among individuals, which lead to the gradual development. On the other hand, self-sufficiency emphasizes that sufficiency relies on individual's competency to fulfill his/her needs with minimal assistance or cooperation from external factors. (b) The misconception that PSE is anti-globalization and may lead to the closing-up of the economy: One may perceive PSE as a concept of nationalism or protectionism since PSE emphasizes the importance of individuals, locality, and the country. Based on such perceptions, one can interpret that the essence of PSE is to encourage individuals to consume domestically, as well as to prevent other countries from entering its domestic market. In fact, PSE is not an antiglobalization concept. Instead, the philosophy is aligned with the neoclassical economy and consistent with capitalism and globalization. PSE suggests that in order to effectively respond to globalization, the local foundations of domestic economy have to be efficiently developed through the utilization of its resources and abilities to enhance the level of competitiveness. Once these developments have been achieved, the country can expose its economy to globalization at its appropriate pace based on its state of readiness. This explanation of PSE is consistent with the fundamental principle of capitalism which refers to the economic and social systems based on the individual rights, resulting in progressive economic development. Additionally, prior research on sociology proposes 
that PSE is the only philosophy which was developed based on the Buddhism philosophy that welcomes both capitalism and globalization (Noy 2011). (c) The misconception that PSE is restricted only to the agriculture context and rural areas: Even though PSE was firstly introduced to the agricultural context, this philosophy stresses the importance of sustainable management and development of individuals, families, communities, and nation. These factors were considered to be the basis of national development.

The second challenge lies within the country of origin, where PSE was first established, Thailand. Thailand is a developing country which embraces unique characteristics, i.e., the country is administered under the constitutional monarchy, agriculture plays a dominant role in its economy, its national religion is Buddhism, and it is a collectivist country. One may question the application of PSE, whether this philosophy is only restricted to countries that exhibit comparable characteristics to Thailand. Other concerns may fall within the credibility of the philosophy's origin. One might argue that such an economic development concept that was developed in a developing country may exhibit a lack of effectiveness and relevancy when handling challenges derived from globalization and market turbulence.

The prominent outcomes of implementing PSE are still questionable. This is because Thailand is still experiencing political and economic instability, poverty, and the degradation of natural resources. Although PSE was integrated to Thailand's $10^{\text {th }}$ National Economic and Social Development Plan (from October 1, 2006 to September 30, 2011) by the interim government of Prime Minister General Surayud Chulanont (Chalapati 2008), the acceptance and implementation of the concept are still limited. It has been argued that the contemporary culture -postmodernity, has actively influenced individuals to exhibit their identity using the symbolic meaning of brands, leisure, and lifestyle pursuits (Shankar Elliott and Fitchett 2009). These effects may limit the implementation of PSE due to the difficulties in changing individual attitudes and behaviors towards the principles of the philosophy. This struggle is mainly due to the misconceptions of PSE as mentioned earlier.

Therefore, national media recently transmit success stories about those who incorporated PSE into their way of lives as well as businesses to encourage Thai people to implement the concept of PSE in their activities. For instance, the national media frequently broadcasted the stories of best practice farmers who integrate PSE to their agricultural businesses across the country (Agriculture and Cooperative 2019). These farmers also offer guidelines regarding the PSE implementation, based on their individual 
experiences, to encourage other farmers and those who are interested in this philosophy to obtain a better understanding of the concept.

In terms of the business sector, the story of Siam Cement Group Public Company Limited (SCG) -one of the oldest and largest firms in Thailand, and how the company successfully adopted PSE as its guiding principle has been widely publicized. SCG restructured and refocused on its core business where it is strongly competitive (moderation and knowledge). It also emphasizes risk management in order to generate greater resiliency (reasonableness). SCG also sets its priority to its human resource development program to enhance the quality of its workforces, resulting in a greater ability to respond to uncertainties (self-immunity). Additionally, the company engages in a wide range of corporate social responsibility activities not only to support nearby community development and environmental preservation, but also to prevent other undesirable social causes. SCG also ensures that all its activities, including both administrative and manufacturing, do not generate a negative effect on its employees, nearby communities, and the environment (morality).

In conclusion, the above challenges of PSE mainly occur from the misconception of the PSE concept. By acknowledging the challenges above, the following section demonstrates the implication of the philosophy of sufficiency economy at the individual level. 


\section{The Implication of Philosophy of Sufficiency Economy at Individual Level}

The philosophy of sufficiency economy can serve as a valuable guideline for individuals, businesses, and communities to improve quality of life, sustainable development, and enhancing human well-being. Since we argue in this paper that individual level inquiry is vital for every society, individual's understanding and ability to adapt their way of life to the concept of PSE is crucial. Therefore, the purpose of this section is to demonstrate how individuals can accommodate PSE in their everyday life activities in order to obtain a more balanced way of living.

Individuals can embrace PSE in their daily activities to enhance their conscience, resulting in a happy and moderate "way of life." Upon reflection, the primary consideration derived from the concepts of PSE is to enhance individual awareness in terms of self-realization. This can be applied through the scrutinized evaluation of daily consumptions in order to alleviate any unnecessary consumption.

In contemporary consumer society, people are actively influenced by a diversity of marketing messages, which may restrict them to behave sustainably and increase the possibility of over-consumption, due to the fact they are likely to present their desired identity through the use of symbolic meanings, leisure, and lifestyle pursuits offered by brands. PSE principles can be useful to conscious consumers when evaluating their purchase decisions. They can consider the following criteria: first, whether the price of the product is appropriate to their resources such as income; second, whether the types of product, its features, and prices are reasonable. In this case, consumers need to ensure that the underlying reason for purchasing such product is based on its utility, not to flaunt that they have acquired the product that can enhance their desired identity. Third, consumers should consider the effects of any uncontrollable factors that might reinforce their vulnerabilities regarding their response to the market turbulence. Additionally, the important aspect of PSE, in terms of daily consumption, is the "mindset" of an individual whether such consumption is based on the foundation of self-realization. Therefore, the individual's appropriate and reasonable product will vary depending on his/her condition, as well as the recent economic context.

In addition, the application of PSE is not limited to any specific context. Instead, the philosophy offers individuals with the guidelines which can be applied to any types of individual consumption. As a result, individuals who understand and sufficiently adopt the concept of PSE to their everyday activities can enhance their ability to cope with any 
uncontrollable factors affecting their daily consumption while being environmentally and socially responsible.

\section{Conclusion}

The Philosophy of Sufficiency Economy highlights the foundation building, enhancing immunities and resilience in a globalized and modernized economic condition with the objectives of generating self-realization and resilient and sustainable development. These objectives can offer individuals the ability to effectively and efficiently handle the challenges resulting from globalization and other related alteration. Although the implementation of PSE is still limited, national media, as well as Thai government have been extensively publicizing the concept to encourage Thai people to adopt the concept of PSE for their daily activities. However, one of the challenges regarding the implementation of PSE is to embrace it at the individual level, applying it into daily activities to enhance individual conscientiousness, which will result in a moderate "way of life." PSE can provide individuals with the ability to protect and defend themselves from any uncontrollable or unexpected factors that are associated with globalization and market turbulence. In addition, we believe that once the concept of PSE is understood sufficiently, adequately, and properly, it could offer researchers a new venue to explore alternative ways of living through the recognition of self-reliance. 


\section{References}

Antràs, Pol, Alonso de Gortari and Oleg Itskhoki (2017), "Globalization, Inequality and Welfare", Journal of International Economics, 108 (C), 387-412. https://doi.org/10.1016/j.jinteco.2017.07.009

Archibugi, Daniele and Simona lammarino (2002), "The Globalization of Technological Innovation: Definition and Evidence", Review of International Political Economy, 9 (1), 98-122. https://doi.org/10.1080/09692290110101126

Baker, Chris and Pasuk Phongpaichit (2014), A History of Thailand: Cambridge University Press.

Bergh, Andreas and Therese Nilsson (2014), "Is Globalization Reducing Absolute Poverty?", World Development, 62, 42-61. https://doi.org/10.1016/j.worlddev.2014.04.007

Bourguignon, François (2016), "Inequality and Globalization: How the Rich get richer as the Poor catch up", Foreign Affairs, (accessed on September 29, 2019), [available at: https://www.foreignaffairs.com/articles/2015-12-14/inequality-andglobalization].

Buranapin, Siriwut and Thankawin Ratthawatankul (2015), "Philosophy of Sufficiency Economy and Business Sustainability: A Framework for Operational Implications", Journal of Business and Behavioral Sciences, 27 (1), 115-41. https://doi.org/108530198

Chaipattana Foundation (2017), "Philosophy of Sufficiency Economy", Chaipattana Foundation, (accessed on March 5, 2019), [available at: http://www.chaipat.or.th/eng/concepts-theories/sufficiencyeconomy-new-theory.html].

Chalapati, Supaporn (2008), "Sufficiency economy as a Response to the Problem of Poverty in Thailand", Asian Social Science, 4 (7), 3-6. https://doi.org/10.5539/ass.v4n7p3

Cook, David and Michael B. Devereux (2006), "External Currency Pricing and the East Asian Crisis", Journal of International Economics, 69 (1), 37-63. https://doi.org/10.1016/j.jinteco.2005.06.010

Dayley, Robert (2011), "Thailand's Agrarian Myth and its Proponents", Journal of Asian and African Studies, 46 (4), 342-60. https://doi.org/10.1177/0021909611400547 
Durham, Frank D. (2007), "Framing the State in Globalization: The Financial Times ' Coverage of the 1997 Thai Currency Crisis", Critical Studies in Media Communication, $24 \quad$ (1), 57-76. https://doi.org/10.1080/07393180701214538

Erturk, Korkut A. (2001), "Overcapacity and the East Asian Crisis", Journal of Post Keynesian Economics, 24 (2), 253-75. https://doi.org/10.1080/01603477.2001.11490326

Ghosh, Swati R. (2013), East-Asian Crisis of 1997: Elsevier Inc.

Giddens, Anthony (2007), The Consequences of Modernity. Standford, CA: Stanford University Press.

International Monetary Fund (2017), "Household Debt, Loans and Debt Securities", IMF, (accessed on September 29, 2019), [available at: https://www.imf.org/external/datamapper/HH LS@GDD/CAN/GBR/ USA/DEU/ITA/FRA/JPN/THA/FADGDWORLD].

Jairak, Kallaya, Prasong Praneetpolgrang and Pilastpongs Subsermsri (2015), "Information Technology Governance Practices based on Sufficiency Economy Philosophy in the Thai University Sector", Information Technology and People, 28 (1), 195-223. https://doi.org/10.1108/ITP-10-2013-0188

Mahathanaseth, Itthipong and Loren W. Tauer (2014), "Performance of Thailand Banks after the 1997 East Asian Financial Crisis", Applied Economics, $46 \quad$ (30), $1-14$. https://doi.org/10.1080/00036846.2014.937036

Ministry of Agriculture and Cooperative (2019), "The Philosophers", Ministry of Agriculture and Cooperative, (access on September 29, 2019), [available at: https://www.moac.go.th/philosopher-philosophersuffice]

Mongsawad, Prasopchoke (2010), "The Philosophy of the Sufficiency Economy: a Contribution to the Theory of Development", Asia-Pacific $\begin{array}{llll}\text { Development Journal, } & 17 & \text { (1), }\end{array}$ https://doi.org/10.18356/cb961558-en

Noy, Darren (2011), "Thailand's Sufficiency economy: Origins and Comparisons with other Systems of Religious Economics", Social Compass, $\quad 58 \quad$ (4), 593-610. https://doi.org/10.1177/0037768611423463

Piboolsravut, Priyanut (2004), "Sufficiency Economy", ASEAN Economic Bulletin, 21 (1), 127-34. https://www.jstor.org/stable/25773806 
Poungsuk, Pakkapong, Nawarat Pourpan and Phaitoon Thongsuk (2016), "Using the Philosophy of Sufficiency Economy (PSE) in High School Agricultural Teaching in Northeastern (Isan) Thailand", Asian International Journal of Social Sciences, 16 (1), 116-27. https://doi.org/10.29139/aijss.20160106

Pruetipibultham, Oranuch (2010), "The Sufficiency Economy Philosophy and Strategic HRD: a Sustainable Development for Thailand", Human Resource Development International, 13 (1), 99-110. https://doi.org/10.1080/13678861003589073

Reese, Gerhard, Amir Rosenmann and Craig McGarty (2015), "Globalisation and Global Concern: Developing a Social Psychology of Human Responses to Global Challenges", European Journal of Social Psychology, $45 \quad$ (7), https://doi.org/10.1002/ejsp.2176

Régnier, Philippe (2017), Small and Medium Enterprises in Distress: Thailand, the East Asian Crisis and beyond: Thailand, the East Asian Crisis and Beyond. Routledge.

Sachayansrisakul, Navarat (2012), "Sufficiency Economy: A Reasonable Approach for Thailand's Future", NIDA Development Journal, 49 (2), 1-22. https://doi.org/10.14456/ndj.2009.18

Scholte, Ja (2008), “Defining Globalization”, World Economy, 31 (11), 1471502. https://doi.org/10.1111//.1467-9701.2007.01019.x

Shankar, Avi, Richard Elliott and James A. Fitchett (2009), "Identity, Consumption and Narratives of Socialization", Marketing Theory, 9 (1), 75-94. https://doi.org/10.1177/1470593108100062

Smith, David A. (2005), "Neoliberal Globalization and Resistance: a Retrospective Look at the East Asian Crisis", eds. Robinson, I. W. and Applebaum P.R., Critical Globalization Studies, Routledge: New York and London

Sornsri, Suppasit (2016), "The Possibility of Applying the Philosophy of Sufficiency Economy in Organizational Purchasing", Umwelt Wirtschafts Forum. https://doi.org/10.1007/s00550-016-0433-4

Tangvitoontham, Nantarat, Suwimon Hengpatana and Polpat Kotrajaras (2015), "Philosophy of Sufficiency Economy, Environmental Protection and Natural Research Conservation Behaviors", International Journal of Arts and Sciences, 8 (4), 125-34. https://doi.org/10.1016/j.kjss.2016.03.002 
Wanasilp, Wanakiti and Nantarat Tangvitoontham (2015), "The Relationship between the Understanding of Philosophy of Sufficiency Economy and the Living Standard: The Case Study of Sufficiency Economy Community in lower Northern Region of Thailand", International Journal of Business Economic Development, 3 (1), 87-95. https://doi.org/10.18356/02bd5fb3-en

Warr, Peter G. (2002), "Thailand," in East Asia in Crisis: From Being a Miracle to Needing One, Ross Garnaut and Ross H. McLeod, eds. Routledge.

Wibulswasdi, Chaiyawat, Priyanut Piboolsravut and Kobsak Pootrakool (2011), Sufficiency Economy Philosophy and Development. Sufficiency Economy Research Project, Bureau of the Crown Property. 